\title{
Chapter 17 \\ Radiocesium Contamination \\ on a University Campus and in Forests \\ in Kashiwa City, Chiba Prefecture, \\ a Suburb of Metropolitan Tokyo
}

\author{
Kenji Fukuda
}

\begin{abstract}
Kashiwa, a city in Chiba Prefecture, became the most contaminated suburb of Metropolitan Tokyo after the Fukushima Daiichi nuclear accident. The Kashiwa Campus of the University of Tokyo and nearby urban forests were surveyed to examine the distribution of radiocesium in the aboveground parts of trees, turf grass, and soil. The air dose rate $1 \mathrm{~m}$ aboveground in the summer of 2011 was $0.3-0.6 \mu \mathrm{Sv} / \mathrm{h}$ and more than $90 \%$ of the radiocesium was in the surface soil. A nursery lawn was effectively decontaminated by removing the turf and surface soil using a sod cutter. In the forests, the radiocesium concentration was higher in the leaves of evergreen trees and outer bark of trees, while the total amount of radiocesium in the aboveground parts of trees was less than $10 \%$ of the amount in the surface soil. Therefore, decontamination by cutting trees would not be effective. The decrease in the radiocesium concentration in the surface soil could be explained by natural decay, while the effects of cesium movement to deeper soil were not prominent.
\end{abstract}

Keywords Contamination in a University Campus · Vegetation cover · Cesium distribution in trees $\cdot$ Soil contamination $\cdot$ Decontamination of lawn

\subsection{Introduction}

Kashiwa is a city located in northwestern Chiba Prefecture. One of the satellite cities around Metropolitan Tokyo, it is located about $30 \mathrm{~km}$ northeast of the center of Tokyo. The landscape is a mosaic of urbanized areas around train stations, residential areas, farmland, factories, and secondary forests. Kashiwa and the surrounding

\footnotetext{
K. Fukuda $(\bowtie)$

Department of Forest Science, Graduate School of Agricultural and Life Sciences,

The University of Tokyo, Tokyo, Japan

e-mail: fukuda@fr.a.u-tokyo.ac.jp
} 
Tokatsu area suffered from the most serious radiocesium contamination in suburban Tokyo after the Fukushima Daiichi accident in March 2011. The estimated contamination by ${ }^{134} \mathrm{Cs}$ and ${ }^{137} \mathrm{Cs}$ totaled $60-100 \mathrm{kBq} / \mathrm{m}^{2}$ in September 2011 according to a contamination map produced by airplane monitoring (MEXT 2016).

The Kashiwa Campus is one of the three main Campuses of the University of Tokyo (UTokyo Campus hereafter), and it has a children's nursery (Kashiwa Donguri Day Nursery). To ensure safety, the radiocesium contamination on the Campus and in nearby forests was surveyed in the summer of 2011, and decontamination of the nursery lawn was attempted in October 2011 (Fukuda et al. 2013a; Kitoh 2013). To estimate the radiocesium distribution in suburban Satoyama forests (i.e., located within $1 \mathrm{~km}$ from Campus), the radiocesium contamination was surveyed in the aboveground parts of thinned trees and in litter and surface soil samples collected from the winter of 2011 to the winter of 2014. The details of Satoyama forests were previously reported in Fukuda et al. (2013b).

\subsection{Study Area and Methods}

The study was conducted in three areas: the UTokyo Campus, Oaota Forest, and Konbukuro Park, which are 1-3 km distant from one another (Fig. 17.1). On the UTokyo Campus, the air dose rate was measured in a remnant secondary deciduous and evergreen oak forest, Campus green areas (planted deciduous and evergreen trees), lawns and grassland, tree pits planted with Zelkova serrata and Rhododendron indicum, and paved areas. The air dose rate was measured $1 \mathrm{~m}$ and 1 or $5 \mathrm{~cm}$ above the ground using a $\mathrm{NaI}(\mathrm{Tl})$ scintillation survey meter (Hitachi, Aloka TCS-171 or Clearpulse, Mr. Gamma A2700). Soil cores up to $20 \mathrm{~cm}$ in depth were taken from several points on the Campus using a liner hand auger (Daiki, DIK-100C). A line transect was set from a forest patch and bamboo stand to grassland in an unused area on the UTokyo Campus in the summer of 2013, and the air dose rate was measured, and soil cores collected (100 mL: 0-5 cm depths) at 10-m intervals.

In Konbukuro Park, the land cover is a mosaic of conifer plantations, deciduous and evergreen broadleaved forests, and wetland vegetation. There, the air dose rate was measured along a footpath, and leaf, litter, and soil samples were taken.

Oaota is also a mosaic of small patches of private conifer and deciduous broadleaf forests with a total area of about 50 ha. We set study plots in a conifer-deciduous mixed stand, deciduous broadleaf stand, grassland, and bamboo bush. The air dose rate was measured in each plot, and leaf and litter samples were taken. Leaf samples, mushrooms, and insects were collected randomly from these forest plots.

The radiocesium concentration of each sample was measured using a $\mathrm{NaI}(\mathrm{Tl})$ scintillation counter (Hitachi, Aloka Auto-well gamma counter ARC-370 M) in the Radioisotope Laboratory of the Graduate School of Frontier Science, UTokyo.

In addition, some trees were felled in the conifer and deciduous stands to estimate the aboveground contamination of forest stands, and $100-\mathrm{mL}$ soil core samples were collected. After thinning in Oaota Forest in the winter of 2011, six trees (two 


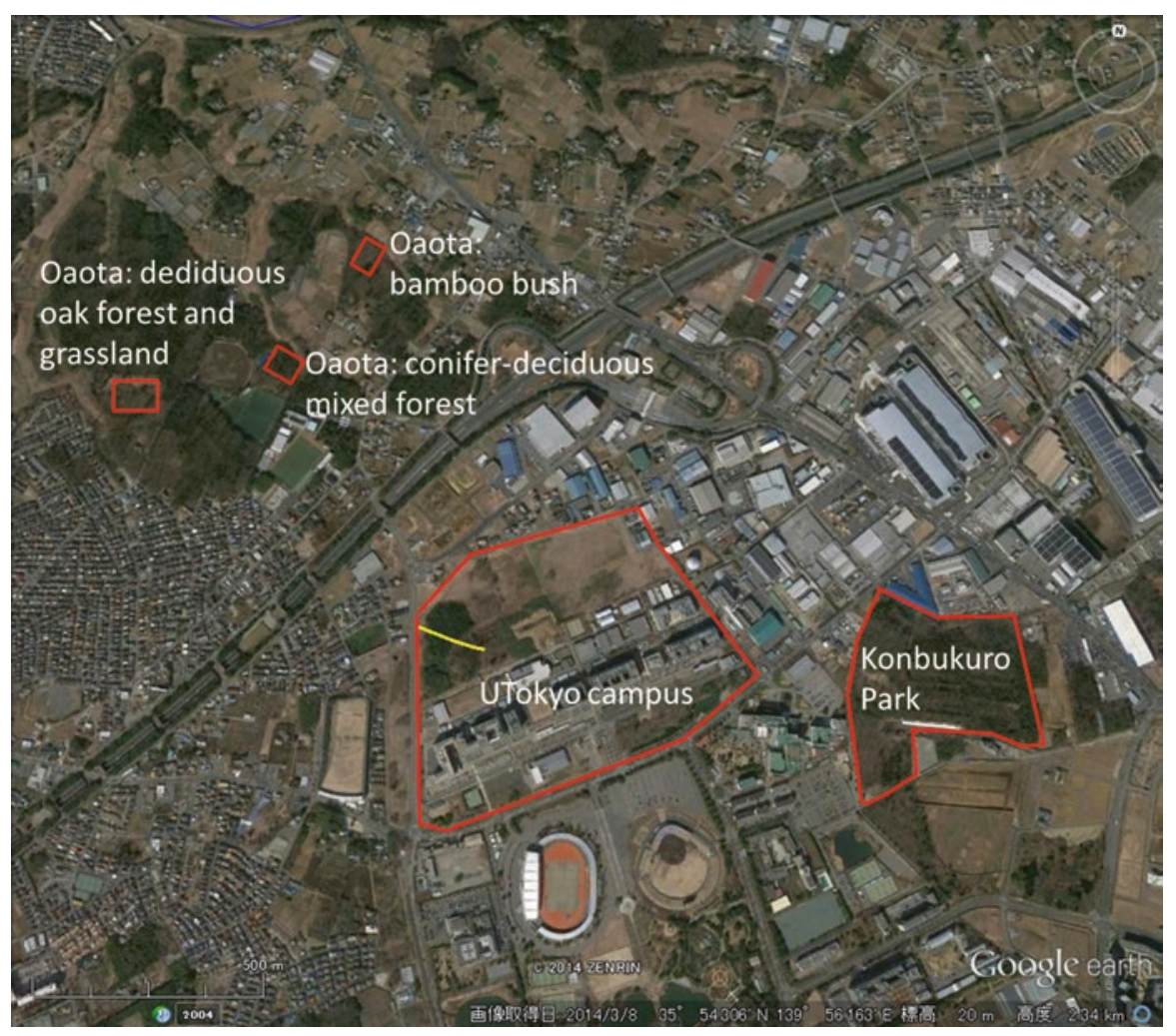

Fig. 17.1 Study sites (plotted on a Google Earth image)

The yellow line in UTokyo Campus shows the line transect

Chamaecyparis obtusa and two Carpinus tshonoskii from a mixed conifer-deciduous stand and two Quercus serrata from a deciduous stand) were sampled to estimate the distribution of radiocesium in standing trees. Immediately after the trees were felled, wood discs were sampled at 0.3 and $1.3 \mathrm{~m}$ aboveground and at 4-m intervals to the tree top, and one to three 2-m-long branches were sampled from the top and bottom of each crown. The disks were oven-dried and divided into outer bark, inner bark, current-year annual ring, sapwood, and heartwood. The branches were divided into branch, old leaves, new leaves, cones, and winter buds and ovendried. The dried samples were cut into small pieces and milled in a coffee mill, and the radiocesium concentration was measured.

Litter samples of the L- and FH-layers were taken from nine $0.2 \times 0.2-\mathrm{m}^{2}$ quadrats set in two forest stands (a mixed conifer-deciduous stand and a deciduous oak stand) in Oaota Forest in the winters of 2012, 2013, and 2014. At the same time, a $100-\mathrm{mL}$ soil core was taken from the center of each quadrat, divided into $1-\mathrm{cm}$ depths, and weighed after oven drying. The radiocesium concentrations of the litter and soil samples were measured to estimate the soil contamination by radiocesium concentration per ground area. 


\subsection{Air Dose Rate and Soil Contamination in 2011 in Relation to the Land Cover}

Table 17.1 summarizes the air dose rates measured from August to November of 2011. On the UTokyo Campus, the Campus greenery and lawns showed a roughly uniform contamination level of $0.3 \sim 0.4 \mu \mathrm{Sv} / \mathrm{h}$ at $1 \mathrm{~m}$ aboveground regardless of the land use, such as forest floor, forest edge, lawn, and bare ground. The air dose rate was lowest on the granite benches, where rainwater washed the polished smooth surface $(0.28 \mu \mathrm{Sv} / \mathrm{h})$, while asphalt and the concrete pavement had air dose rates similar to or higher than those of the forest floor and lawn. The rough surface asperity of the pavement served as a reservoir for radiocesium-containing mud particles. A drainage pit and the pavement edge receiving rainwater from paved areas had the highest air dose rates, where clay particles and organic compounds in soil concentrated radiocesium.

Table 17.1 Air dose rate $(\mu \mathrm{Sv} / \mathrm{h})$ and land cover at the study sites

\begin{tabular}{|c|c|c|c|c|}
\hline Land cover & Month & $\begin{array}{l}\text { Number } \\
\text { of points }\end{array}$ & $1 \sim 5 \mathrm{~cm}$ & $1 \mathrm{~m}$ \\
\hline UTokyo Campus & Aug.-Nov. 2011 & & & \\
\hline Asphalt \& concrete pavement & & 45 & $0.54 \pm 0.19$ & $0.38 \pm 0.10$ \\
\hline Natural stone bench & & 6 & $0.28 \pm 0.09$ & $0.28 \pm 0.09$ \\
\hline Drainage, Pavement edge & & 92 & $0.99 \pm 0.58$ & $0.42 \pm 0.12$ \\
\hline Water canal's edge & & 4 & $0.29 \pm 0.06$ & $0.26 \pm 0.04$ \\
\hline Lawn & & 88 & $0.52 \pm 0.19$ & $0.38 \pm 0.08$ \\
\hline Bare soil & & 11 & $0.48 \pm 0.12$ & $0.31 \pm 0.05$ \\
\hline Tree planting pit & & 29 & $0.58 \pm 0.34$ & $0.36 \pm 0.08$ \\
\hline Forest edge & & 13 & $0.46 \pm 0.09$ & $0.36 \pm 0.03$ \\
\hline Forest center & & 37 & $0.63 \pm 0.40$ & $0.40 \pm 0.09$ \\
\hline Konbukuro Park & Dec. 2011 & & & \\
\hline Grassland & & 5 & $0.39 \pm 0.04$ & $0.35 \pm 0.03$ \\
\hline $\begin{array}{l}\text { Pleioblastus chino bamboo } \\
\text { bush }\end{array}$ & & 2 & $0.35 \pm 0.00$ & $0.33 \pm 0.01$ \\
\hline Evergreen forest stand & & 15 & $0.36 \pm 0.05$ & $0.32 \pm 0.03$ \\
\hline Decidous forest stand & & 15 & $0.36 \pm 0.06$ & $0.32 \pm 0.03$ \\
\hline Forest edge & & 27 & $0.36 \pm 0.10$ & $0.30 \pm 0.05$ \\
\hline Side of the drainage canal & & 8 & $1.16 \pm 1.05$ & $0.78 \pm 0.31$ \\
\hline \multicolumn{5}{|l|}{ Oaota forest } \\
\hline $\begin{array}{l}\text { Conifer-deciduous mixed: } \\
\text { thinned }\end{array}$ & July 2013 & 56 & $0.28 \pm 0.11$ & $0.14 \pm 0.01$ \\
\hline Deciduous oak: thinned & Nov. 2012 & 18 & $0.34 \pm 0.13$ & $0.19 \pm 0.02$ \\
\hline Deciduous oak: control & June 2013 & 15 & $0.28 \pm 0.03$ & $0.23 \pm 0.02$ \\
\hline
\end{tabular}

Modified from Fukuda et al. (2013b) 
In Konbukuro Park, the air dose rate was $0.30 \sim 0.35 \mu \mathrm{Sv} / \mathrm{h}$ at $1 \mathrm{~m}$ aboveground regardless of forest type. A drainage canal at the northern edge of the park had the highest contamination, $0.78 \mu \mathrm{Sv} / \mathrm{h}$, after collecting rainwater from surrounding areas including a road gutter. Benten Pond, a spring which is supplied by shallow groundwater, had the lowest radiocesium concentration in the sediment (Fukuda et al. 2013b).

In Oaota Forest, a conifer stand and a deciduous stand thinned after the Fukushima accident had lower air dose rates $(0.1 \sim 0.2 \mu \mathrm{Sv} / \mathrm{h})$ than did non-thinned stands and other forests in Konbukuro Park and UTokyo.

Figure 17.2 shows the radiocesium measured in soil cores sampled on the UTokyo Campus in the summer of 2011. Soil contamination was higher at the edges of the lawn and a planting pit, which receive rainwater from pavement and asphalt roads, than it was in the center of the lawn and pit, respectively. In an area of planted trees, deposition was higher at the forest edge. In the lawn center, radiocesium deposition was concentrated at $0 \sim 1-\mathrm{cm}$ depth, while in the forest, where there was almost no herbaceous vegetation or litter layer, radiocesium was distributed to $5 \mathrm{~cm}$ or deeper. The turfgrass shoots, thatch, and root mat of the lawn seemed to have intercepted radiocesium-contaminated rain effectively, preventing penetration into the soil. This suggests that the decontamination of lawns would be relatively easy, by removing the turf grass and shallow surface soil.

\subsection{Radiocesium Concentrations in Biological Samples}

Table 17.2 summarizes the radiocesium concentrations in living leaves, fungi, and litter samples. Old leaves of evergreen conifers and branches of some deciduous trees and shrubs that were contaminated directly after the Fukushima accident had higher concentrations, while the leaves of deciduous trees, which flushed after the accident, had lower values. New leaves of evergreen conifers and broadleaves had higher values than did leaves of deciduous trees, indicating the translocation of radiocesium from contaminated old shoots to newly developed shoots (IAEA 2006; Tagami et al. 2012; Yoshihara et al. 2013; Masumori et al. 2015a, b; Tagami et al. 2012; Takata 2013, 2015). Mushrooms contained a range of radiocesium concentrations, with some wood-rotting species and ectomycorrhizal species having extraordinarily high levels, 36-60 kBq/kg (dry weight), indicating bioconcentration of radiocesium by these fungi (e.g., Yoshida and Muramatsu 1994; Yamada 2013). In Oaota Forest, citizen volunteers help with the management of the forest, as contracted between a volunteer NPO (a non-profit organization) and the landowner. The volunteers used the thinned oak wood as fuel for BBQs and as bed logs for cultivating shiitake mushrooms on the forest floor. The shiitake mushrooms cultivated there had higher radiocesium concentrations than the government reference level $(0.1 \mathrm{kBq} / \mathrm{kg})$. 

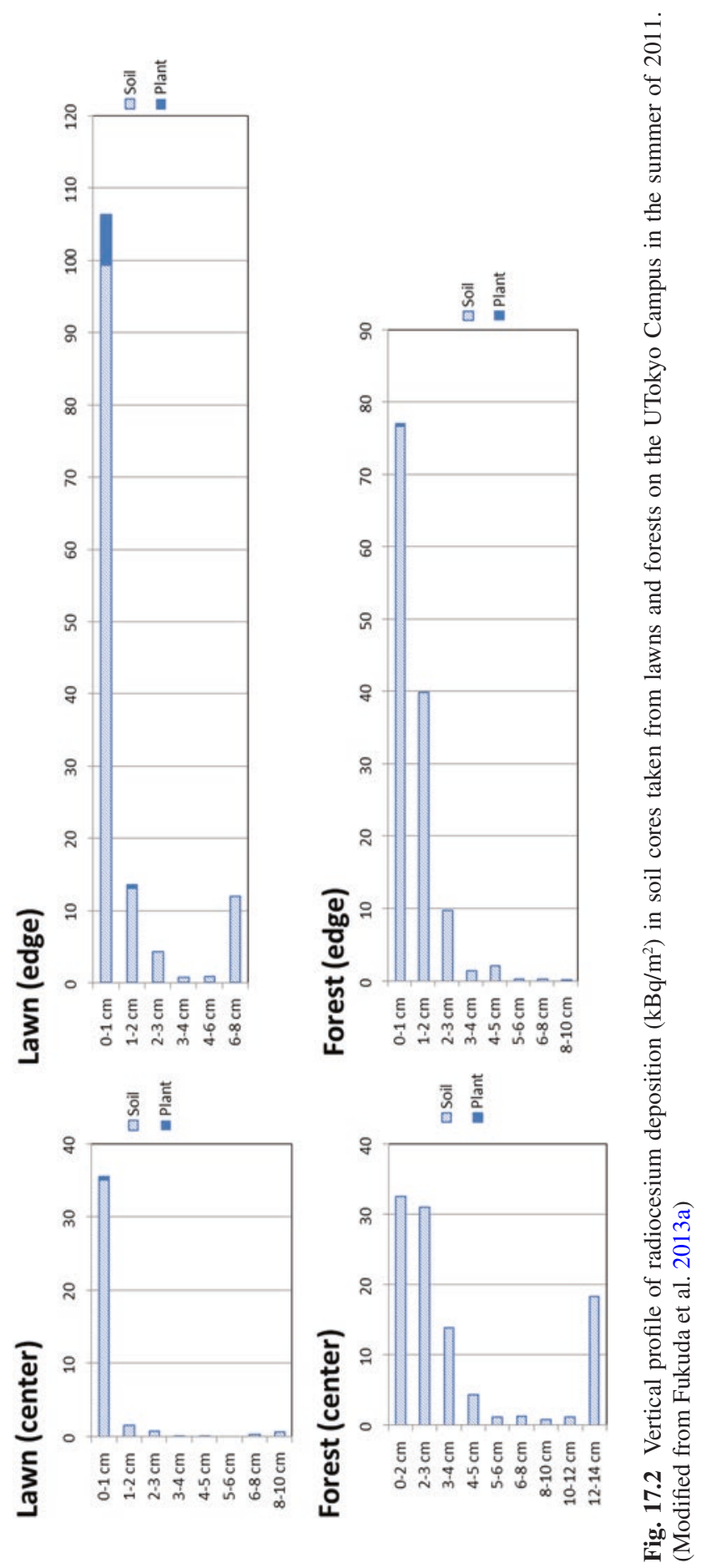


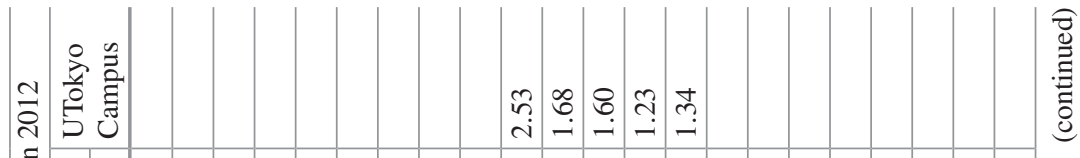

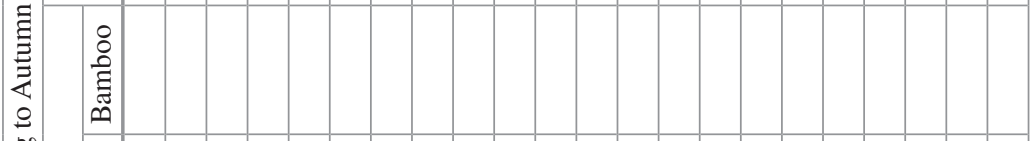

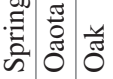

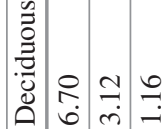

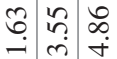

竞㐫

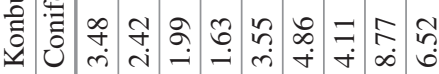

m.

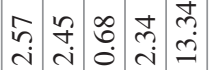

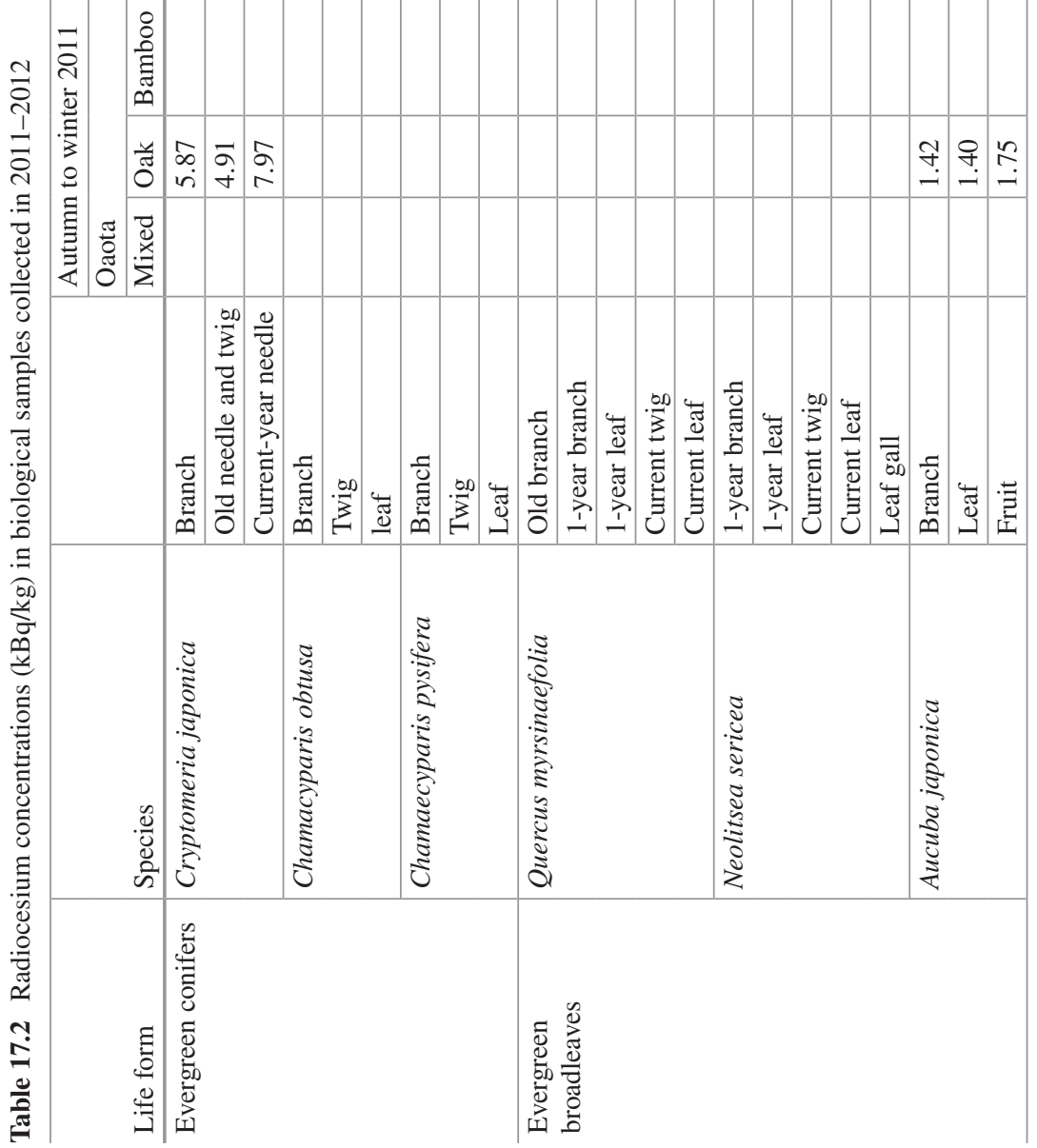




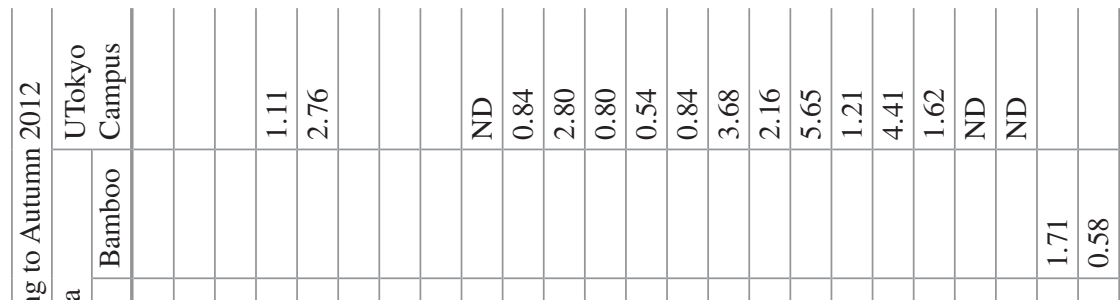
言

\begin{tabular}{lll}
\hline \\
\hline
\end{tabular}

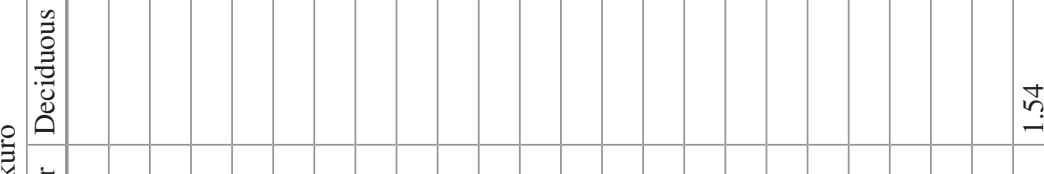

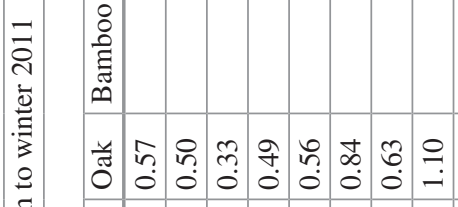

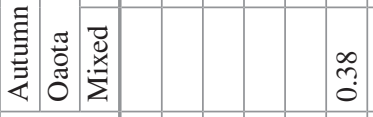

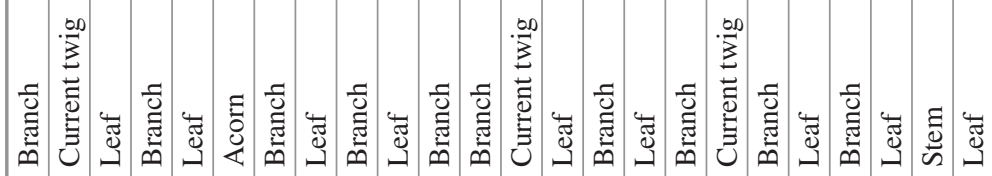

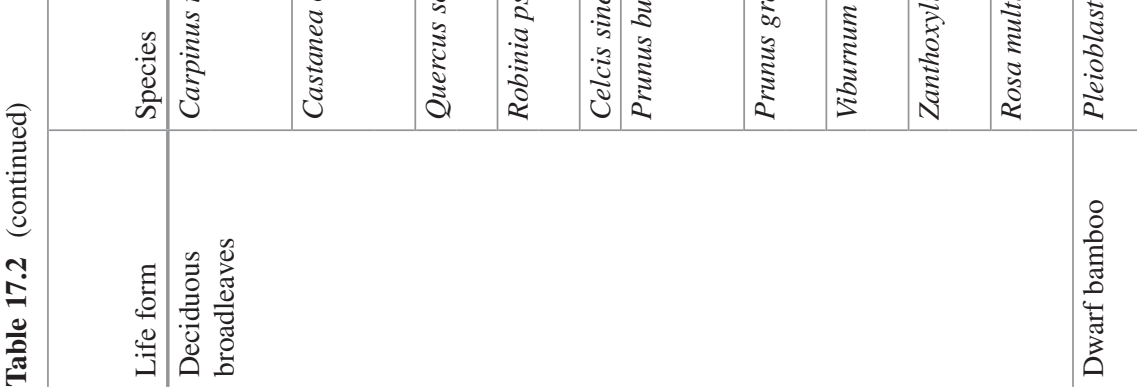




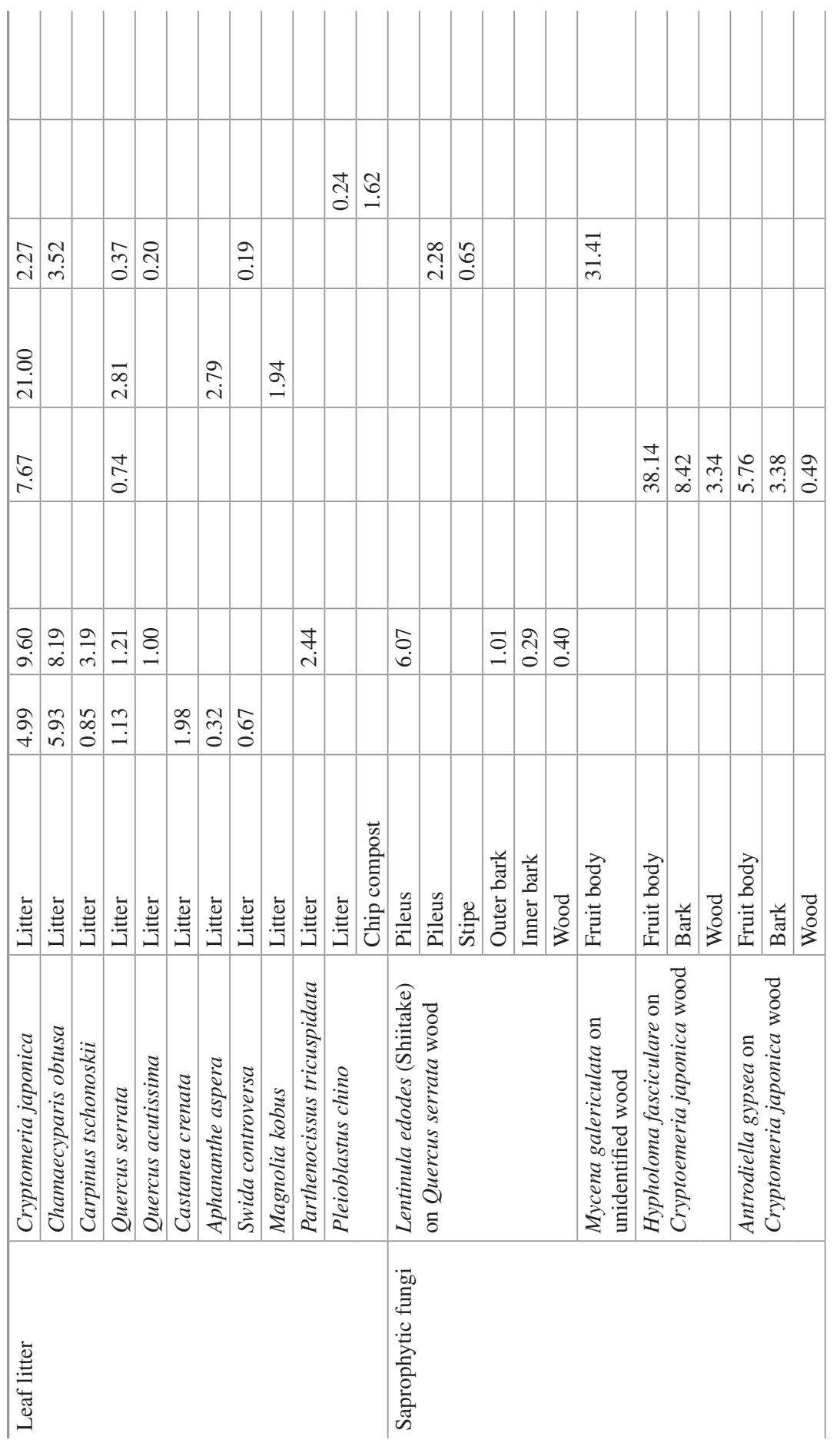




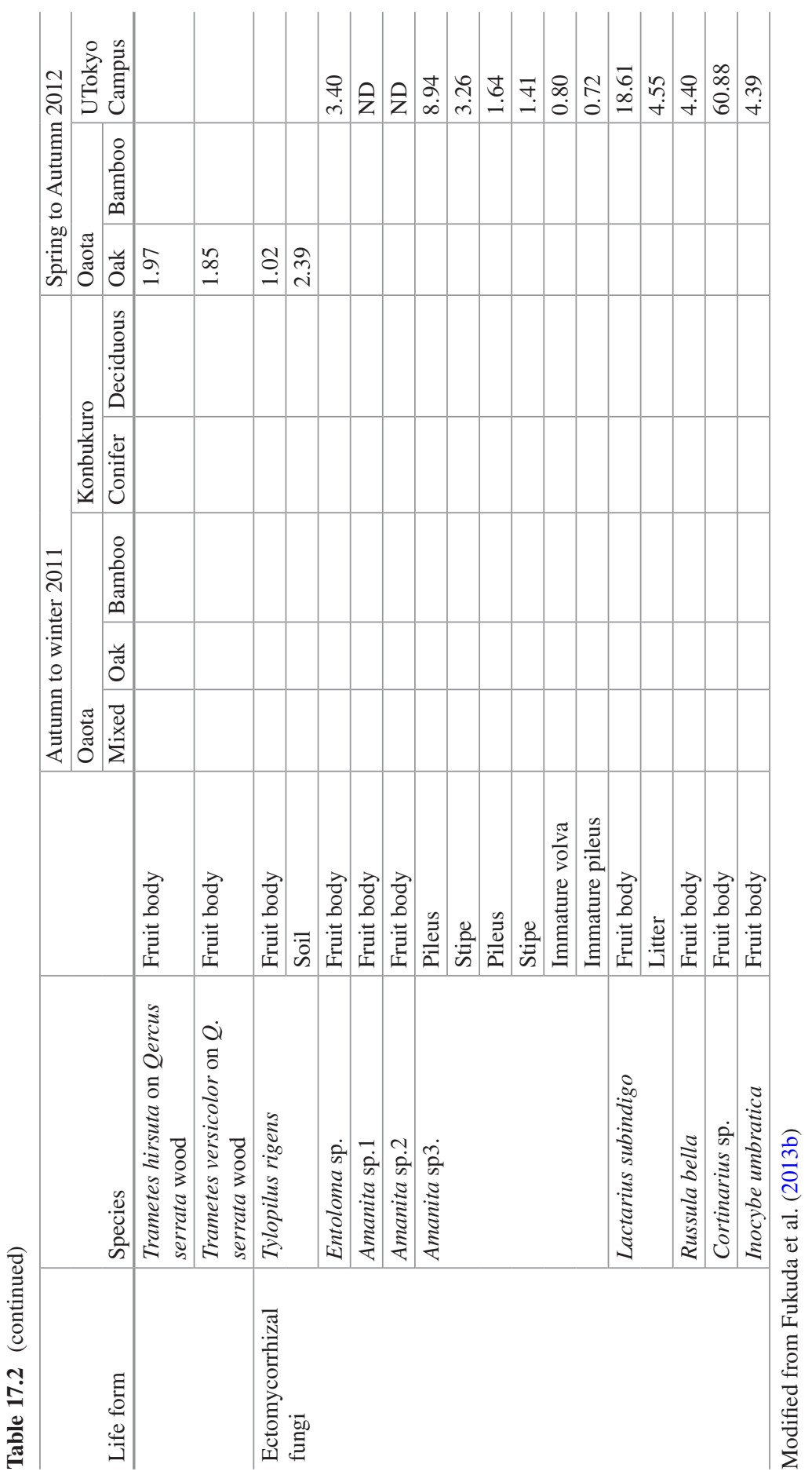




\subsection{Radiocesium Contamination in Forest Trees and Soil in the Winter of 2011}

Figure 17.3 shows the radiocesium distributions in the felled trees. The lower branches of Chamaecyparis obtusa (Hinoki) had the highest contamination load, and the outer bark of the upper stem had the highest load in the stem. For Carpinus tshonoskii (Inushide) trees, the outer bark at a height of $0.8 \mathrm{~m}$ and above had a high contamination load. The outer bark of Quercus serrata (Konara) at a height of $10 \mathrm{~m}$ had the highest level of contamination. In all tree species, the sapwood and some heartwood samples showed radiocesium contamination. The general trend of the radiocesium distribution in the aboveground parts of standing trees was similar to that in Fukushima Prefecture (Kaneko and Tsuboyama 2012; Kato et al. 2012; Koarashi et al. 2012; Kuroda et al. 2013; Masumori et al. 2015a, b; Miura 2015; Ohashi et al. 2014; Ohte et al. 2015) (Figs. 17.4 and 17.5).

Tables 17.3 and 17.4 summarize the total deposition of radiocesium in the aboveground parts of forest trees in these stands. Each tree contained $40-113 \mathrm{kBq}$, and the total estimated deposition was $3.7-5.7 \mathrm{kBq} / \mathrm{m}^{2}$. The radiocesium deposition in soil was roughly estimated to be $50-90 \mathrm{kBq} / \mathrm{m}^{2}$ (Fukuda et al. 2013b). Therefore, more than $90 \%$ of the radiocesium contamination was deposited on the soil surface in the mixed and deciduous forests in this area, concurring with some low-level contaminated sites in Fukushima Prefecture (Kaneko and Tsuboyama 2012; Kuroda et al. 2013). Therefore, decontamination by cutting trees or collecting litter would not be effective in these forests.

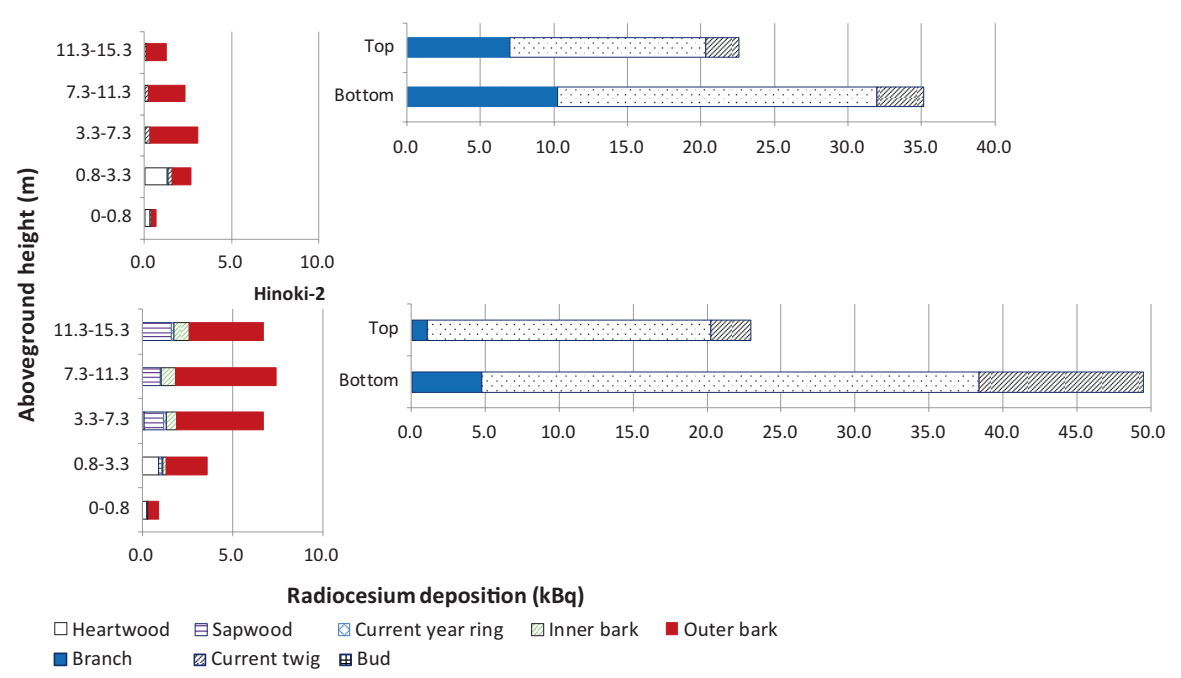

Fig. 17.3 Aboveground deposition of radiocesium $(\mathrm{kBq})$ in trees felled in Oaota Forest in the winter of 2011. (Modified from Fukuda et al. 2013b)

Hinoki: Chamaecyparis obtusa 


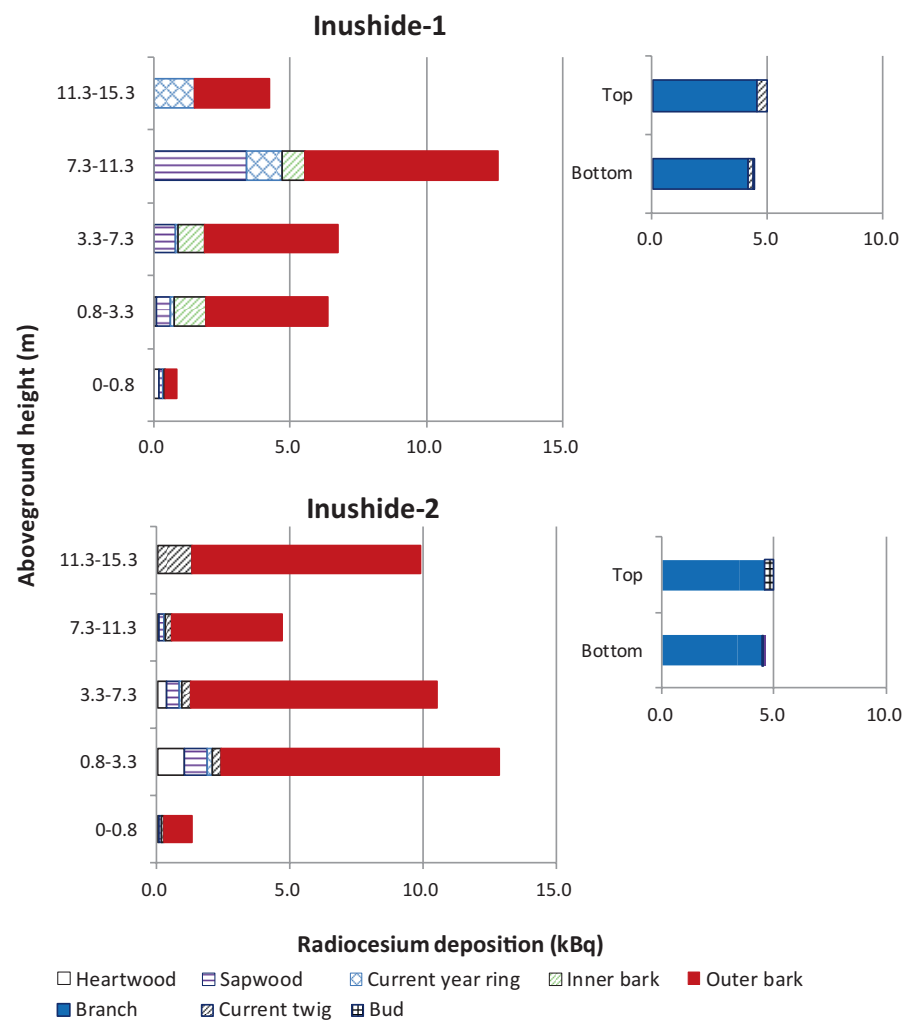

Fig. 17.4 Aboveground deposition of radiocesium $(\mathrm{kBq})$ in trees felled in Oaota Forest in the winter of 2011. (Modified from Fukuda et al. 2013b)

Inushide: Carpinus tschonoskii

\subsection{Forest Type, Air Dose Rate, and Soil Contamination in the UTokyo Campus Forest in 2013}

In the summer of 2013, the air dose rate and surface soil contamination were surveyed along a line transect on the UTokyo Campus (Fig. 17.6). The air dose rate fluctuated around $0.2 \mu \mathrm{Sv} / \mathrm{h}$, which is about one-half the level recorded in the summer of 2011. In this unused area of the Campus, no decontamination effort was undertaken; therefore, the decrease in the air dose rate was solely attributed to the natural decay and movement of radiocesium into the soil. Soil contamination differed significantly among the land cover types. The total deposition of radiocesium in 0 5$\mathrm{cm}$ soil was highest at a canal into which rainwater could flow, and it was relatively high on bare land (unpaved road) and under a deciduous tree canopy. The contamination level was low under the dense tall bamboo stand and in the soil under the evergreen tree canopy. Although the radiocesium deposition in the aboveground parts of bamboo and evergreen trees was not estimated in this forest, we postulate that the evergreen canopy intercepted the radiocesium deposition (Hashimoto et al. 2012; Kaneko and Tsuboyama 2012), and decontamination by cutting trees and bamboo 


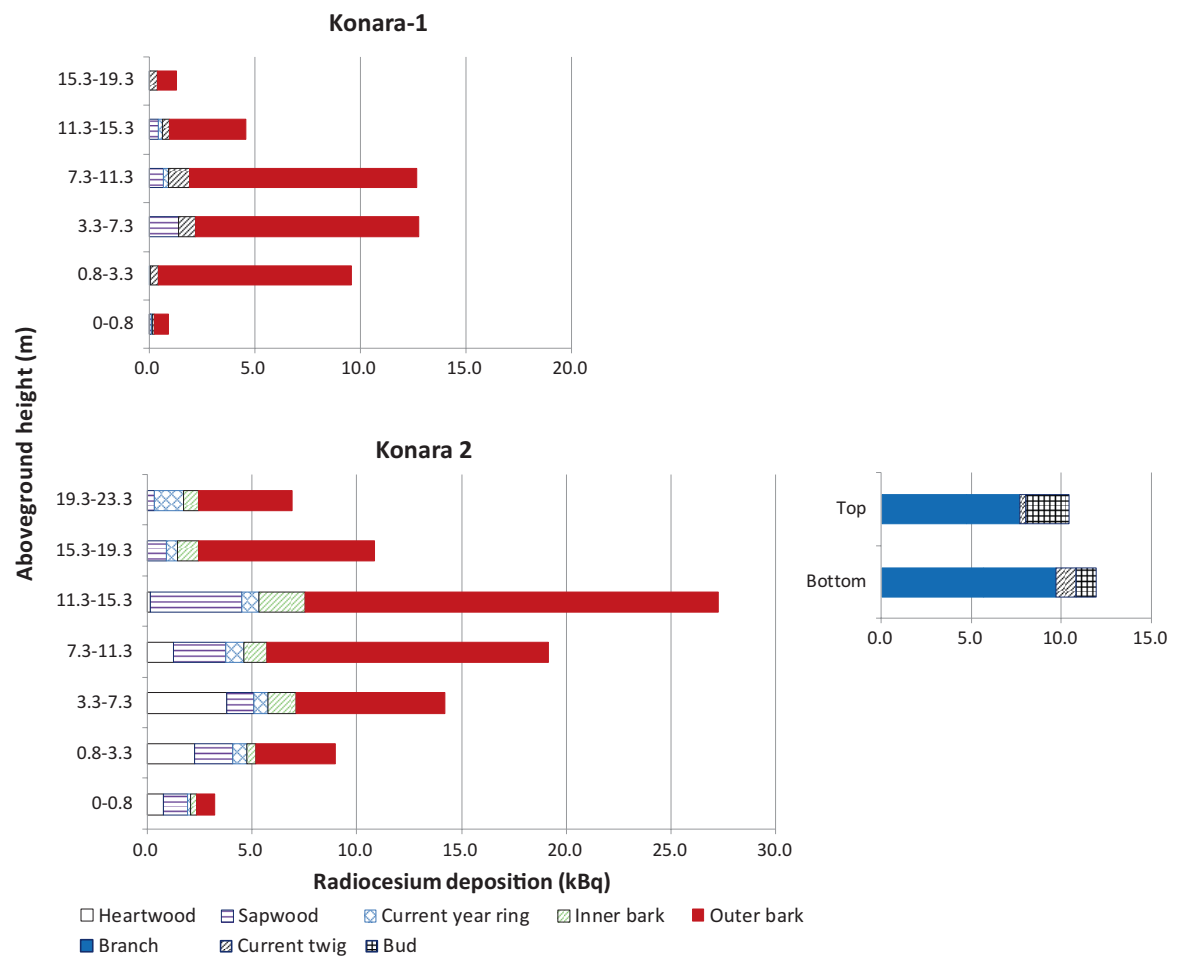

Fig. 17.5 Aboveground deposition of radiocesium $(\mathrm{kBq})$ in trees felled in Oaota Forest in the winter of 2011. (Modified from Fukuda et al. 2013b)

Konara: Quercus serrata

might be effective in bamboo stands and evergreen forests. In deciduous forests, radiocesium was thought to be concentrated in surface soil, so decontamination would be much more difficult.

\subsection{Decontamination Experiment in a Nursery Lawn}

In the autumn of 2011, a decontamination experiment was conducted in the lawn of the nursery on the UTokyo Campus (Fukuda et al. 2013a). Based on the vertical distribution of radiocesium contamination in the lawn soil (Fig. 17.2, upper), removing the turfgrass and surface soil was thought to be effective. Therefore, the area within $10 \mathrm{~m}$ of the nursery building was treated with a sod cutter (Iwamoto TS-1F) which removed $2 \mathrm{~cm}$ of surface soil with the turf root mat (Fig. 17.7, left). A second decontamination method recommended in Fukushima Prefecture, which involved removing turfgrass shoots and thatch with a reel (Kyoei LM22) and rotary mowers (Kyoei GM530C) and preserving the turf roots to reduce the cost of returfing, was 
Table 17.3 Aboveground deposition of radiocesium in trees felled in Oaota Forest estimated in the winter of 2011

\begin{tabular}{|c|c|c|c|c|c|c|c|}
\hline & \multirow{2}{*}{$\begin{array}{l}\text { Plot } \\
\text { Tree }\end{array}$} & \multicolumn{4}{|c|}{ Conifer-deciduous mixed forest } & \multicolumn{2}{|c|}{$\begin{array}{l}\text { Deciduous oak } \\
\text { forest }\end{array}$} \\
\hline & & $\begin{array}{l}\text { Hinoki } \\
1\end{array}$ & $\begin{array}{l}\text { Hinoki } \\
2\end{array}$ & $\begin{array}{l}\text { Inushide } \\
1\end{array}$ & $\begin{array}{l}\text { Inushide } \\
2\end{array}$ & $\begin{array}{l}\text { Konara } \\
1\end{array}$ & $\begin{array}{l}\text { Konara } \\
2\end{array}$ \\
\hline & $\mathrm{DBH}(\mathrm{cm})$ & 19.5 & 17.4 & 20.0 & 20.0 & 23.4 & 34.9 \\
\hline & $\mathrm{H}(\mathrm{m})$ & 15 & 16.9 & 19.0 & 16.5 & 20.1 & 21.1 \\
\hline & $\mathrm{BA}\left(\mathrm{cm}^{3}\right)$ & 299 & 238 & 314 & 314 & 430 & 957 \\
\hline \multirow[t]{2}{*}{ Dry weight (kg) } & Stem & 86.0 & 92.0 & 150.6 & 132.2 & 228.9 & 659.1 \\
\hline & $\begin{array}{l}\text { Branches \& } \\
\text { leaves }\end{array}$ & 25.8 & 23.3 & 39.9 & 39.9 & 38.4 & 89.6 \\
\hline \multirow{2}{*}{$\begin{array}{l}\text { Radiocesium } \\
\text { deposition }(\mathrm{kBq})\end{array}$} & Stem & 10.0 & 25.5 & 30.9 & 39.3 & 41.9 & 90.7 \\
\hline & $\begin{array}{l}\text { Branches \& } \\
\text { leaves }\end{array}$ & 57.7 & 72.5 & 9.4 & 9.5 & 9.6 & 22.3 \\
\hline \multicolumn{2}{|c|}{$\begin{array}{l}\text { Total radiocesium depositon }(\mathrm{kBq} / \\
\text { tree) }\end{array}$} & 67.7 & 97.9 & 40.3 & 48.8 & 51.5 & 113.0 \\
\hline \multicolumn{2}{|c|}{$\begin{array}{l}\text { Radiocesium deposition per BA } \\
\left(\mathrm{kBq} / \mathrm{cm}^{2}\right)\end{array}$} & 0.227 & 0.412 & 0.128 & 0.155 & 0.120 & 0.118 \\
\hline
\end{tabular}

Modified from Fukuda et al. (2013b)

Hinoki: Chamaecyparis obtusa

Inushide: Carpinus tschonoskii

Konara: Quercus serrata

Table 17.4 Stand-level deposition of radiocesium in Oaota Forest

\begin{tabular}{|c|c|c|c|}
\hline \multicolumn{2}{|l|}{ Land cover } & $\begin{array}{l}\text { Conifer-deciduous mixed } \\
\text { forest }\end{array}$ & $\begin{array}{l}\text { Deciduous } \\
\text { forest }\end{array}$ \\
\hline \multirow{2}{*}{\multicolumn{2}{|c|}{ Dominant species }} & Chamaecyparis obtusa & Querus serrata \\
\hline & & Carpinus tschonoskii & Q. accutissima \\
\hline \multicolumn{2}{|l|}{ Number of species } & 9 & 5 \\
\hline \multicolumn{2}{|l|}{ Max DBH $(\mathrm{cm})$} & 35.0 & 36.6 \\
\hline \multicolumn{2}{|l|}{ Max H (m) } & 22.0 & 22.1 \\
\hline \multicolumn{2}{|l|}{ Stem density (/ha) } & 1175 & 725 \\
\hline \multicolumn{2}{|l|}{ Total BA (m²/ha) } & 25.3 & 30.9 \\
\hline \multirow[t]{3}{*}{$\mathrm{BA}\left(\mathrm{m}^{2} / \mathrm{ha}\right)$} & Conifers & 11.5 & 0.37 \\
\hline & Evergreen broadleaves & 0.21 & 0.00 \\
\hline & Deciduous broadleaves & 13.5 & 30.5 \\
\hline \multirow{4}{*}{$\begin{array}{l}\text { Radiocesium deposition } \\
\text { in trees }\left(\mathrm{kBq} / \mathrm{m}^{2}\right)\end{array}$} & Conifers & 3.69 & 0.12 \\
\hline & Evergreen broadleaves & 0.07 & 0.00 \\
\hline & Deciduous broadleaves & 1.91 & 3.63 \\
\hline & Aboveground total & 5.67 & 3.74 \\
\hline \multicolumn{2}{|c|}{ Radiocesium deposition in soil $\left(\mathrm{kBq} / \mathrm{m}^{2}\right)$} & 60 & 85 \\
\hline \multicolumn{2}{|c|}{ Total deposition $\left(\mathrm{kBq} / \mathrm{m}^{2}\right)$} & 70 & 90 \\
\hline
\end{tabular}

Modified from Fukuda et al. (2013b) 


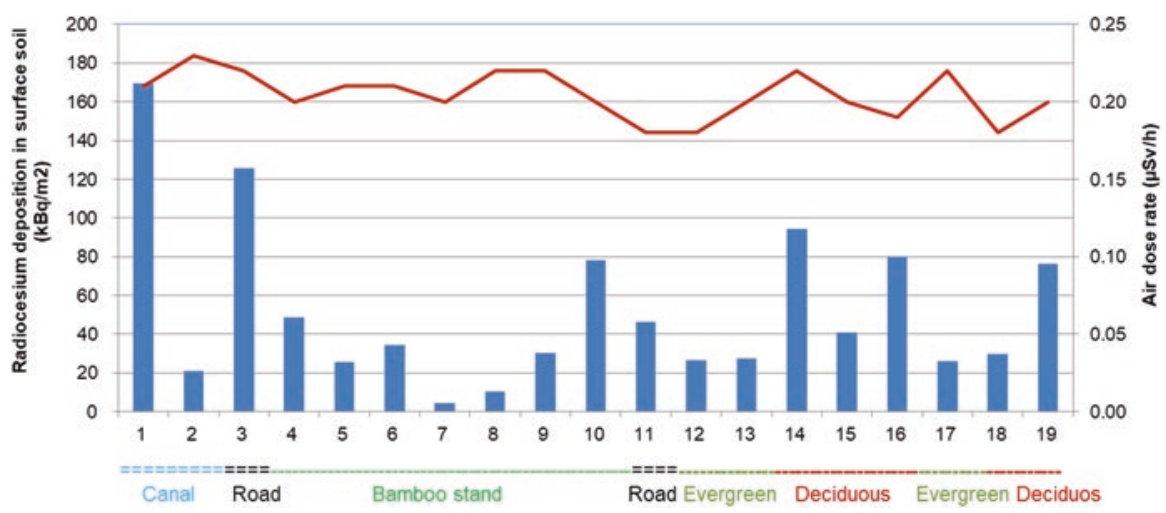

Fig. 17.6 Air dose rate at $1 \mathrm{~m}$ above the ground (red line) and radiocesium deposition in $0-5 \mathrm{~cm}$ surface soil (blue bars) along a transect on the UTokyo Campus measured in the summer of 2013

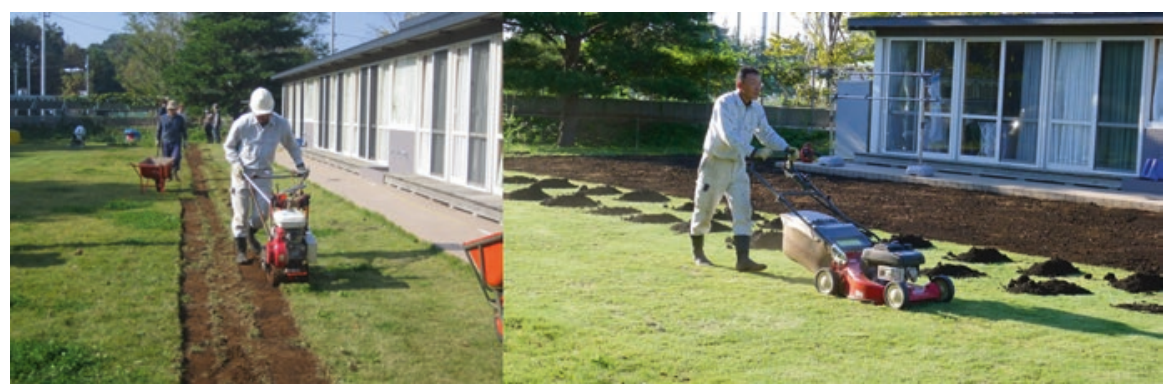

Fig. 17.7 The decontamination experiment conducted on a nursery lawn on the UTokyo Campus (Fukuda et al. 2013a)

Left: A sod-cutter removing the root mat of turf with $2 \mathrm{~cm}$ of surface soil. Right: A rotary mower collecting thatch and the cover soil preparation (the bare area in front of the nursery building had been treated by sod-cutting method)

also tested in the outer area (Fig. 17.7, right). The results are shown in Table 17.5. Removing soil with the root mat effectively decreased the air dose rate at $5 \mathrm{~cm}$ aboveground to $0.13 \mu \mathrm{Sv} / \mathrm{h}$, while the low-cost method failed to reduce the air dose rate sufficiently. This clearly demonstrated that to reduce the air dose rate of the lawn, it is important to remove the contaminated surface soil.

\subsection{Change in Radiocesium Distribution in Deciduous Forest Soil in Oaota in 2013-2015}

The vertical distribution of radiocesium in the surface soil samples collected in the deciduous forest of Oaota over a 3 year period is shown in Fig. 17.8. These observations showed that the movement of radiocesium into deeper soil was very slow, as 
Table 17.5 Effect of decontamination of a lawn by sod-cutting (removing the root mat with 2-cm of surface soil) and mowing (low-cost method) on air dose rate $(\mu \mathrm{Sv} / \mathrm{h})$ at $5 \mathrm{~cm}$ above the ground in 2011

\begin{tabular}{l|l|l|l|l}
\hline & Date & Control & Sod-cutting & Mowing \\
\hline Before decontamination & Sept. 13 & $0.54 \pm 0.16$ & $0.67 \pm 0.24$ & $0.53 \pm 0.03$ \\
\hline After mowing & Oct. 29 & - & - & $0.49 \pm 0.10$ \\
\hline After sod-cutting & Oct. 29 & - & $0.16 \pm 0.02$ & - \\
\hline After covering soil & Oct. 29 & - & $0.13 \pm 0.02$ & $0.42 \pm 0.02$ \\
\hline After 2 weeks & Nov. 15 & $0.49 \pm 0.11$ & $0.12 \pm 0.05$ & $0.42 \pm 0.03$ \\
\hline After 2 months & Jan. 17 & $0.52 \pm 0.14$ & $0.16 \pm 0.04$ & $0.43 \pm 0.04$ \\
\hline
\end{tabular}

Modified from Fukuda et al. (2013a)

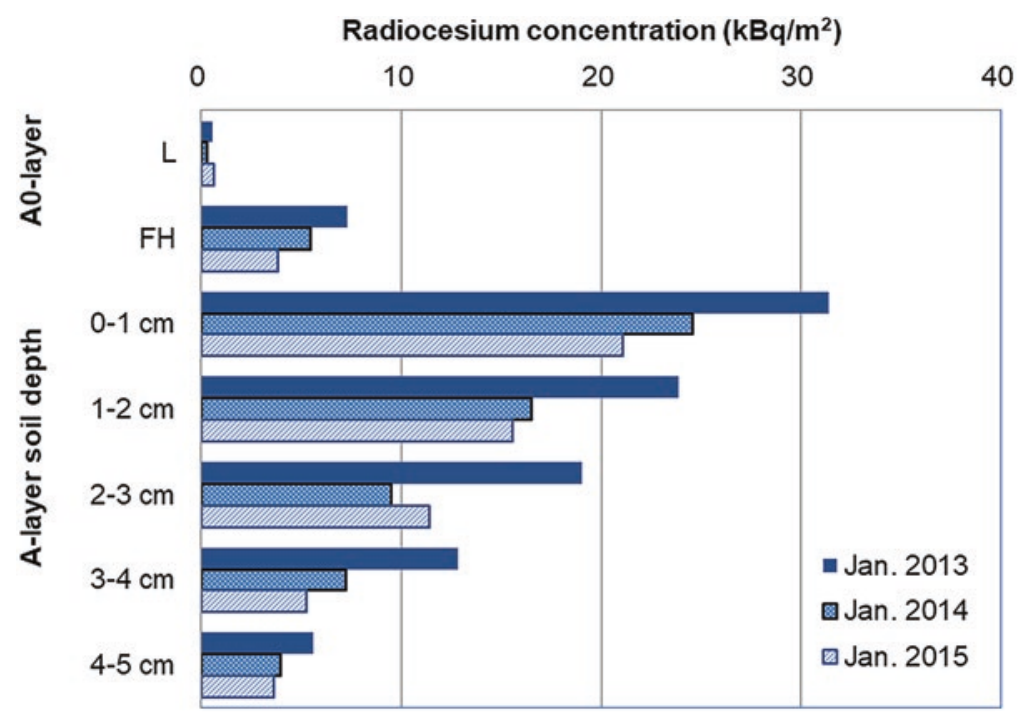

Fig. 17.8 Vertical distribution of radiocesium deposition in the deciduous oak stand in Oaota Forest

has been suggested in many other studies (IAEA 2006; Shiozawa 2013; Yamaguchi et al. 2012). The decrease in radiocesium concentration could be explained by the natural decay of ${ }^{134} \mathrm{Cs}$, which accounted for about half the level in 2011. Therefore, the subsequent decrease in radiocesium concentration will slow down, because ${ }^{137} \mathrm{Cs}$ with its longer half-life remains in the soil. The absorption of radiocesium by tree roots and ectomycorrhizal fungi should be monitored carefully to predict the dynamics of radiocesium in Satoyama forest ecosystems. 


\subsection{Conclusion}

The total contamination level in the UTokyo Campus and nearby forests matched the deposition map (MEXT 2011). In the lawn on the UTokyo Campus, most of the radiocesium contamination was restricted to the very shallow soil surface $(0-1 \mathrm{~cm})$, and removing soil with the root mat was effective for reducing the air dose rate in the lawn. In evergreen forests and bamboo stands, the soil contamination was lower than that in bare land and deciduous forests. Deciduous forests are the most common vegetation of Satoyama forests, where many citizen volunteers work, and most of the radiocesium deposition in such forests was in the surface soil, making decontamination of deciduous forests difficult. The movement of radiocesium into deeper soil was negligible until the winter of 2014 , and only natural decay seemed to decrease the air dose rate in these forests. Both the sapwood and heartwood of the standing trees were slightly contaminated, suggesting translocation of radiocesium into the tree stem. The use of cut logs for fuelwood and for the cultivation of shiitake mushrooms was impossible in these forests in the winter of 2011. Continued monitoring of the radiocesium dynamics in trees is necessary for the safety of Satoyama citizen volunteers in the hot spot areas of suburban Tokyo.

Acknowledgment I thank Dr. Natsumaro Kutsuna of the Radioisotope Laboratory of the Graduate School of Frontier Sciences, the University of Tokyo, for measuring the radiocesium concentrations in the samples. I also thank Prof. Shuichi Kitoh and the members of the "Donguri Day Nursery Decontamination Project," as well as Prof. Makoto Yokohari, Prof. Hirokazu Yamamoto, Prof. Toru Terada, and the members of Agriculture-Landscape Group of the "JST Urban Reformation Program for the Realization of a Bright Low-Carbon Society Project" for their financial support, discussion, and assistance in the field survey and experiments.

I also thank the members of the Department of Natural Environmental Studies, Graduate School of Frontier Sciences, the University of Tokyo, for their assistance in the line transect survey in 2013, and the volunteers from the NPOs "Chiba Satoyama Trust" and "Konbukuroike Shizenno-Mori" for their kind cooperation with the field survey and sample collection.

\section{References}

Fukuda K, Kutsuna N, Terada T, Mansounia MR, Uddin MN, Jimbo K, Shibuya S, Fujieda J, Yamamoto H, Yokohari M (2013a) Radiocesium contamination in suburban forests in Kashiwa city, Chiba Prefecture. Jpn J For Environ 55:83-98 (in Japanese with English abstract)

Fukuda K, Kutsuna N, Kitoh S, Yamaji E, Saito K, Onuki M, Koibuchi Y, Mitani H, Yoshida Z, Jimbo K, Matsuo Y, Sueyoshi K (2013b) Radioactive cesium contamination in Kashiwa Campus of the University of Tokyo, Chiba prefecture and decontamination experiment for lawn. J Jpn Soc Turfgrass Sci 42:20-30 (in Japanese with English abstract)

Hashimoto S, Ugawa S, Nanko K, Shichi K (2012) The total amounts of radioactively contaminated materials in forests in Fukushima. Jpn Sci Rep 2:416

IAEA (International Atomic Energy Agency) (2006) Environmental consequences of the chernobyl accident and their remediation: twenty years of experience. http://www-pub.iaea.org/ mtcd/publications/pdf/pub1239_web.pdf 
Kaneko S, Tsuboyama Y (2012) Radioactive contamination in forests and its decontamination. Gakujutsu no Doko (in Japanese)

Kato H, Onda Y, Teramage M (2012) Depth distribution of ${ }^{137} \mathrm{Cs},{ }^{134} \mathrm{Cs}$, and ${ }^{131} \mathrm{I}$ in soil profile after Fukushima Dai-ichi Nuclear Power Plant accident. J Environ Radioact 11: 59-64.

Kitoh S (2013) Ethics of scientists facing the low-level contamination caused by Fukushima nuclear accident. In: FGF, TGF (eds) Nuclear disaster and academism: question and action from Fukushima University and the University of Tokyo. Godo Shuppan, Tokyo, pp 80-104 (in Japanese)

Koarashi J, Atarashi-Andoh M, Matsunaga T, Sato T, Nagao S, Nagai H (2012) Factors affecting vertical distribution of Fukushima accident-derived radiocesium in soil under different landuse conditions. Sci Total Environ 431:392-401

Kuroda K, Kagawa A, Tonosaki M (2013) Radiocesium concentrations in the bark, sapwood and heartwood of three tree species collected at Fukushima forests half a year after the Fukushima Dai-ichi nuclear accident. J Environ Radioact 122:37-42

Masumori M, Nogawa N, Sugiura S, Tange T (2015a) Radiocesium in stem, branch and leaf of Cryptemria japonica and Pinus densiflora trees: case of forests in Minamisoma in 2012 and 2013. J Jpn For Soc 97:51-56

Masumori M, Nogawa N, Sugiura S, Tange T (2015b) Radiocesium in tnimber of Japanese cedar and Japanese red pine, in the forests of Minamisoma, Fukushima. In: Nakanishi TM, Tanoi K (eds) Agricultural implications of the Fukushima nuclear accident. Springer, Tokyo, pp 161174. https://doi.org/10.1007/978-4-431-55,828-6_13

MEXT (Japanese Ministry of Education, Culture, Sports, Science, and Technology) (2011-2016) Extension site of distribution map of radiation dose, etc. http://ramap.jmc.or.jp/map/eng/. Accessed 5 Dec 2016

Miura S (2015) The effects of radioactive contamination on the forestry industry and commercial mushroom-log production in Fukushima, Japan. In: Nakanishi TM, Tanoi K (eds) Agricultural implications of the Fukushima nuclear accident. Springer, Tokyo, pp 145-160. https://doi. org/10.1007/978-4-431-55,828-6_12

Ohashi S, Okada N, Tanaka A, Nakai W, Takano S (2014) Radial and vertical distributions of radiocesium in tree stems of $P$. densiflora and Quercus serrata 1.5 y after the Fukushima nuclear disaster. J Environ Radioact 134:54-60

Ohte N, Murakami M, Endo I, Ohashi M, Iseda K, Suzuki T, Oda T, Hotta N, Tanoi K, Kobayashi NI, Ishii N (2015) Ecosystem monitoring of radiocesium redistribution dynamics in a forested catchment in Fukushima after the Nuclear Power Plant accident in March 2011. In: Nakanishi TM, Tanoi K (eds) Agricultural implications of the Fukushima nuclear accident. Springer, Tokyo, pp 175-188. https://doi.org/10.1007/978-4-431-55,828-6_14

Shiozawa S (2013) Vertical migration of radiocesium fallout in soil in Fukushima. In: Nakanishi TM, Tanoi K (eds) Agricultural implications of the Fukushima nuclear accident. Springer, Tokyo, pp 49-60. https://doi.org/10.1007/978-4-431-54,328-2_6

Tagami K, Uchida S, Ishii N, Kagiya S (2012) Translocation of radiocesium from stems and leaves of plants and the effect on radiocesium concentrations in newly emerged plant tissues. J Environ Radioact 111:65-69

Takata D (2013) Distribution of radiocesium from the radioactive fallout in fruit trees. In: Nakanishi TM, Tanoi K (eds) Agricultural implications of the Fukushima nuclear accident. Springer, Tokyo, pp 143-162. https://doi.org/10.1007/978-4-431-54,328-2_14

Takata D (2015) Translocation of radiocesium in fruit trees. In: Nakanishi TM, Tanoi K (eds) Agricultural implications of the Fukushima nuclear accident. Springer, Tokyo, pp 119-144. https://doi.org/10.1007/978-4-431-55,828-6_11

Yamada T (2013) Mushrooms: radioactive contamination of widespread mushrooms in Japan. In: Nakanishi TM, Tanoi K (eds) Agricultural implications of the Fukushima nuclear accident. Springer, Tokyo, pp 163-176. https://doi.org/10.1007/978-4-431-54,328-2_15 
Yamaguchi N, Takada Y, Hayashi K, Ishikawa S, Kuramata M, Eguchi S, Yoshikawa S, Sakaguchi A, Asada K, Wagai R, Makino T, Akahane I, Hiradate S (2012) Behavior of radiocesium in soil-plant systems and its controlling factor. Bull Natl Inst Agro Environ Sci 31:75-129 (in Japanese with English abstract)

Yoshida S, Muramatsu Y (1994) Accumulation of radiocesium in basidiomycetes collected from Japanese forests. Sci Total Environ 157:197-205

Yoshihara T, Matsumura T, Hashida S, Nagaoka T (2013) Radiocesium contaminations of 20 wood species and the corresponding gamma-ray dose rates around the canopies at 5 months after the Fukushima Nuclear Power Plant accident. J Environ Radioact 115:60-68

Open Access This chapter is licensed under the terms of the Creative Commons Attribution 4.0 International License (http://creativecommons.org/licenses/by/4.0/), which permits use, sharing, adaptation, distribution and reproduction in any medium or format, as long as you give appropriate credit to the original author(s) and the source, provide a link to the Creative Commons license and indicate if changes were made.

The images or other third party material in this chapter are included in the chapter's Creative Commons license, unless indicated otherwise in a credit line to the material. If material is not included in the chapter's Creative Commons license and your intended use is not permitted by statutory regulation or exceeds the permitted use, you will need to obtain permission directly from the copyright holder.

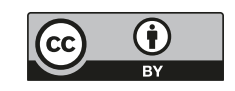

